J. Clin. Chem. Clin. Biochem.

Vol. 25, 1987, pp. $811-821$

(C) 1987 Walter de Gruyter \& Co. Berlin - New York

\title{
Comparison of Two Solid Phase Chemistry Systems: Reflotron and Ektachem DT 60
}

\author{
By Madeleine Rohac and F. Gabl \\ Institute of Clinical Chemistry and Laboratory Medicine, University of Vienna, Vienna, Austria
}

(Received April 27/August 5, 1987)

Summary: Solid phase chemistry can be used for clinical analysis at the bedside, and it is even applicable to whole blood. We compared precision, accuracy, method linearity, and practicability of two solid phase chemistry analysers. Reflotron (Boehringer Mannheim, W. Germany) and Ektachem DT 60 (Eastman Kodak Co, USA). Eight analytes, glucose, cholesterol, triacylglycerols, .urea, uric acid, alanine aminotransferase, aspartate aminotransferase, and $\gamma$-glutamyltransferase were investigated. The precision of both instruments was good. Coefficients of variation for within run and day to day precision were below $10 \%$ for all analytes. Methods were compared by analysing 88 to 105 patient sera for each investigated analyte on Reflotron, on Ektachem DT 60 and on a wet chemistry reference instrument. Linear regression analysis showed good agreement between wet chemistry and solid phase chemistry results. Coefficients of correlation (r) ranged from 0.957 to 0.999 .

Reflotron and Ektachem are desk top analysers. Reflotron is the smaller instrument. Currently, it offers 9 analytes and rapid single test performance. Whole blood can be used for all tests. Test strips can be stored at room temperature. Ektachem DT 60 has a modular design, and 22 analytes are available. Series of up to 100 tests per hour are possible. Whole blood can be used for the preparation of glucose and haemoglobin test slides. The slides must be deep frozen for prolonged storage. Reflotron may be suitable for the physician's office, Ektachem for small laboratories. The problem of quality control has not yet been satisfactorily solved for either instrument, as only analyser-specific control specimens can be used. Reagent costs of solid phase chemistry tests are high, especially when large test series are performed. Operation of both instruments requires well trained personnel.

\section{Introduction}

In recent years solid phase chemistry has been opposed as an alternative technology to conventional wet chemistry techniques in clinical chemistry. One reason for "alternativity" is development of new desk top analysers for laboratory testing at the bedside.

In solid phase chemistry preweighed quantities of dried reagents are fixed on carrier materials. When a liquid sample is added, the subsequent chemical reactions cause a (colour)-intensity change of the reagent carrier. This change is proportional to the analyte concentration in the sample, and it is measured by reflection densitometry. Measurements and calculation of results are performed in special analysers. (1) Users of these instruments are very dependent on the manufacturer for choice of methods, reagent quality and instrument calibration. For this reason, solid phase chemistry is viewed critically by the conventional school of laboratory medicine.

The historical background (2) shows that solid phase chemistry is not at all a new technology, its roots dating back to the 19th century (3). From the qualitative urine analysis of that time, test strip chemical testing developed into semiquantitative blood glucose monitoring in the 1960's. Nowdays a broad spectrum of quantitative solid phase chemistry tests is facili- 
tated by combination of advanced solid phase chemistry technology and adapted microprocessor controlled analysers. Several evaluations of these systems, involving more than single tests, have been carried out $(4-10)$. The aim of our study was to compare precision, accuracy, method linearity and practicability of two solid phase chemistry analysers, Reflotron and Ektachem DT 60. We investigated the analysis of eight analytes, glucose, cholesterol, triacylglycerols, urea, uric acid, alanine aminotransferase, aspartate aminotransferase and $\gamma$-glutamyltransferase.

\section{Materials and Methods}

Our study was carried out in two parts. During the first part (April to May 1986) we tested three analytes glucose, cholesterol and triacylglycerols. In the second part (August to November 1986) two more substrates, urea, uric acid and the newly available procedures for the determination of enzymes alanine aminotransferase, aspartate aminotransferase and $\gamma$-glutamyltransferase were investigated.

\section{Instruments}

Solid phase chemistry analysis was performed on Reflotron (Boehringer Mannheim GmbH, D-6800 Mannheim 31, W. Germany) and on Ektachem DT 60 (Eastman Kodak Co, Rochester, NY 14650, USA).

Both instruments are desk top analysers. The modular design of Ektachem DT 60 consists of a DT-Module for colorimetric testing, a DTE-Module for potentiometric electrolyte testing and a DTSC-Module for continuous enzyme assays.

Reflotron uses cellulose reagent carrier "test strips" (11), Ektachem works with slides consisting of ultrathin multiple film layers $(12,13,14)$. Wet chemistry reference instruments were a Parallel (American Monitor Corp, Indianapolis IN 46268, USA) for cholesterol and triacylglycerols, and a Hitachi 737 (Boehringer Mannheim GmbH, D-6800 Mannheim 31, W. Germany) for other investigated analytes. The Reflotron, Ektachem DT 60 and Parallel Analyser operate at $37^{\circ} \mathrm{C}$, while the working temperature of the Hitachi 737 is $25^{\circ} \mathrm{C}$. Results of enzyme measurements with the Reflotron and Ektachem DT 60 were scaled to $25^{\circ} \mathrm{C}$ by conversion factors (performed by the central processing units of the instruments).

\section{Reagent carriers}

Lot Nos. of the Reflotron test strips:

Glucose 21530932 ,

cholesterol 21509132

triacylglycerols 21531132,

urea 21648141 ,

uric acid 21631931

alanine aminotransferase 21655131 ,

aspartate aminotransferase 23403041 ,

$\gamma$-glutamyltransferase 21616341 .

\section{Lot Nos. of the Ektachem slides:}

Glucose 0054-0312-3229,

cholesterol 0851-0057-5027 / 0851-0069-5027,

triacylglycerols 0751-0065-5027, urea 0151-0312-3229 / 0151-0222-3644 uric acid 0551-0029-0872 / 0551-0032-0932, alanine aminotransferase 6251-0043-5039, aspartate aminotransferase 4851-0019-5101, $\gamma$-glutamyltransferase 6751-0021-5040.

\section{Calibration}

$$
\therefore
$$

Reflotron cannot be calibrated by the operator. Following the manufacturer's recommendations, we calibrated the. Ektachem DT 60 before beginning of each part of study. During the second part we recalibrated once when the instrument was moved. Analyte-specific calibration was necessary for cholesterol, urea and uric acid as the slide lot numbers changed. Lyophilized Ektachem DT 60 calibrators with kit numbers 04, 05,06 were reconstituted and used according to operator's manual.

\section{Precision}

For within run precision we analysed human sera (two concentrations for each analyte, except uric acid) ten times on Reflotron and Ektachem DT 60. Day to day precision was calculated from internal quality control results obtained during a sequence of ten working days.

\section{Quality control}

Daily quality control was performed using analyser-specific control specimens.

For the Reflotron we used

Precinorm U for Reflotron Lot No. 154313

Precipath U for Reflotron Lot No. 154315

For the Ektachem DT 60 we used

Ektachem DT 60 Control Lot No. 158400 / 0401400

Control fluids were prepared according to the instruction manual. Reconstituted Ektachem DT 60 Control was stored in aliquots at $-20^{\circ} \mathrm{C}$ for a maximum period of one month. Controls for the Reflotron were dissolved every second day and kept refrigerated $\left(-4^{\circ} \mathrm{C}\right)$ when not used.

The optical performance of the Reflotron was checked with grey test strips (CHEK strips) every second day. The optical system of Ektachem was checked by a service technologist three times during the period of study.

\section{Method comparison}

We analysed between 88 and 105 fresh patient sera, drawn at random, using the two solid phase chemistry analysers and the reference instrument.

A survey of chemical methods is given in table 1. Results from the solid phase chemistry analysers were compared.with each other and with those from the reference instrument by linear regression analysis. Statistical data were calculated according to the standardized principal component model (15).

\section{Linearity}

Six point dilution series were prepared according to the measuring ranges of the Reflotron and Ektachem 'DT 60. For each investigated analyte we diluted a fresh serum pool containing a high analyte concentration with pool serum containing a low concentration in order to obtain six specimens, containing fractions of $0,0.20,0.40,0.60,0.80$ and 1.00 of the high concentration pool. Each dilution was analysed in triplicate. 
Tab. 1. Analytical chemical methods of solid phase chemistry analysers and wet chemistry reference instruments. Reference instruments:

Parallel (Am. Monitor, USA) for cholesterol and triacylglycerols.

Hitachi 737 (Boehringer Mannheim, W. Germany) for other analytes.

\begin{tabular}{|c|c|c|c|c|c|c|}
\hline \multirow{2}{*}{$\begin{array}{l}\text { Analyte } \\
\text { Glucose }\end{array}$} & \multicolumn{2}{|l|}{ Reflotron } & \multicolumn{2}{|l|}{ Ektachem DT 60} & \multicolumn{2}{|l|}{ Reference } \\
\hline & $\begin{array}{l}\text { Glucose oxidase } \\
\text { Peroxidase }\end{array}$ & $642 \mathrm{~nm}$ & $\begin{array}{l}\text { Glucose oxidase } \\
\text { Peroxidase }\end{array}$ & $555 \mathrm{~nm}$ & $\begin{array}{l}\text { Hexokinase - Glucose-6- } \\
\text { phosphate dehydrogenase }\end{array}$ & $376 \mathrm{~nm}$ \\
\hline Cholesterol & $\begin{array}{l}\text { Cholesterol oxidase } \\
\text { Peroxidase }\end{array}$ & $642 \mathrm{~nm}$ & $\begin{array}{l}\text { Cholesterol oxidase } \\
\text { Peroxidase }\end{array}$ & $555 \mathrm{~nm}$ & $\begin{array}{l}\text { Cholesterol oxidase } \\
\text { Peroxidase }\end{array}$ & $500 \mathrm{~nm}$ \\
\hline Triacylglycerols & $\begin{array}{l}\text { Glycerol kinase, Gly- } \\
\text { cerophosphate oxidase, } \\
\text { Peroxidase }\end{array}$ & $642 \mathrm{~nm}$ & $\begin{array}{l}\text { Glycerol kinase, Gly- } \\
\text { cerophosphate oxidase, } \\
\text { Peroxidase }\end{array}$ & $555 \mathrm{~nm}$ & $\begin{array}{l}\text { Glycerol kinase, Glu- } \\
\text { cose-6-phosphate dehy- } \\
\text { drogenase, American Blue }\end{array}$ & $610 \mathrm{~nm}$ \\
\hline Urea & Urease & $642 \mathrm{~nm}$ & Urease & $660 \mathrm{~nm}$ & $\begin{array}{l}\text { Urease - Glutamate } \\
\text { dehydrogenase }\end{array}$ & $340 \mathrm{~nm}$ \\
\hline Uric acid & Uricase - Peroxidase & $642 \mathrm{~nm}$ & Uricase - Peroxidase & $660 \mathrm{~nm}$ & Uricase - Peroxidase & $660 \mathrm{~nm}$ \\
\hline $\begin{array}{l}\text { Alanine amino- } \\
\text { transferase }\end{array}$ & Pyruvate/Peroxidase & $567 \mathrm{~nm}$ & $\begin{array}{l}\text { NADH/Lactate dehy- } \\
\text { drogenase + Pyridoxal- } \\
\text { 5-phosphate }\end{array}$ & $340 \mathrm{~nm}$ & $\begin{array}{l}\text { Standard method (DGKC) } \\
\text { optimized without py- } \\
\text { ridoxal-5-phosphate }\end{array}$ & $340 \mathrm{~nm}$ \\
\hline $\begin{array}{l}\text { Aspartate amino- } \\
\text { transferase }\end{array}$ & Pyruvate/Peroxidase & $567 \mathrm{~nm}$ & $\begin{array}{l}\text { NADH/Malate dehy- } \\
\text { drogenase + Pyridoxal- } \\
\text { 5-phosphate }\end{array}$ & $340 \mathrm{~nm}$ & $\begin{array}{l}\text { Standard method (DGKC) } \\
\text { optimized, without py- } \\
\text { ridoxal-5-phosphate }\end{array}$ & $340 \mathrm{~nm}$ \\
\hline $\begin{array}{l}\gamma \text {-Glutamyl- } \\
\text { transferase }\end{array}$ & $\begin{array}{l}\text { Substrate: } \\
\gamma \text {-Glutamyl- } \\
p \text {-phenyldiamine-3- } \\
\text { carbonic acid }\end{array}$ & $642 \mathrm{~nm}$ & $\begin{array}{l}\text { Method of Szasz, } \\
\text { L-glutamic acid } \\
\text { 5-(4-nitroanilide) }\end{array}$ & $400 \mathrm{~nm}$ & $\begin{array}{l}\text { Method of Szasz \& Persijn, } \\
\text { L-glutamic acid 5-(3- } \\
\text { carboxy-4-nitroanilide) }\end{array}$ & $415 \mathrm{~nm}$ \\
\hline
\end{tabular}

\section{Results}

\section{Precision}

Good precision was found for all eight analytes on both solid phase chemistry instruments.

Coefficients of variation of within run precision ranged from $1.0 \%$ (glucose "high") to $5.1 \%$ (urea "high") on the Reflotron; from $0.6 \%$ (glucose "high") to $9.4 \%$ (aspartate aminotransferase "low") on the Ektachem DT 60 . For day to day precision, coefficients of variation lay between $2.4 \%$ (glucose) and $8.3 \%$ (triacylglycerols) on the Reflotron and between $1.4 \%$ (aspartate aminotransferase) and 3.7\% (urea) on the Ektachem DT 60.

Detailed values are shown in tables 2 and 3. There was no apparent difference between the precision of the Reflotron and the Ektachem. Enzyme continuous assays were as precise as substrate determinations. Within run and day to day precision studies gave similar results. The striking difference between the coefficient of variation of within run and day to day precision of aspartate aminotransferase on the Ektachem may be explained by differences between mean values of samples (11.3 U/1, within run, human serum) and $132 \mathrm{U} / \mathrm{l}$ (day to day, control fluid).

\section{Method comparisons}

Good agreement was found between wet chemistry and solid phase chemistry analyses of human serum. Plots of linear regression analysis are presented in figures $1 \mathrm{a}-1 \mathrm{c}$, statistical data in table 4. Comparison of the Reflotron and the wet chemistry reference instrument showed coefficients of correlation (r) between 0.953 (cholesterol) and 0.998 (alanine aminotransferase, aspartate aminotransferase); enzyme determinations with the Reflotron showed an even better correlation with wet chemistry results.

Coefficients of correlation from the comparative study of the Ektachem DT 60 and wet chemistry instrument ranged from 0.966 (aspartate aminotransferase) to 0.999 (glucose and $\gamma$-glutamyltransferase).

When results from the two solid phase chemistry analysers were compared with each other, rather poor correlations were obtained for two analytes, i.e. aspartate aminotransferase $(r=0.957)$ and cholesterol $(r=0.946)$. No significant difference was found between the relative accuracy of measurements of the Reflotron and Ektachem (Wilcoxon test, $\alpha=0.10$ ). 
Tab. 2. Within run precision; $\mathrm{n}=10$; human sera.

\begin{tabular}{|c|c|c|c|c|c|c|}
\hline & \multicolumn{3}{|c|}{ Reflotron } & \multicolumn{3}{|c|}{ Ektachem DT 60} \\
\hline & $\overline{\mathbf{x}}$ & $\mathrm{SD}$ & $\mathrm{CV}(\%)$ & $\overline{\mathbf{x}}$ & $\mathrm{SD}$ & $\mathrm{CV}(\%)$ \\
\hline Glucose $\mathrm{mmol} / \mathrm{l}$ & $\begin{array}{r}2.40 \\
14.50\end{array}$ & $\begin{array}{l}0.05 \\
0.15\end{array}$ & $\begin{array}{l}2.4 \\
1.0\end{array}$ & $\begin{array}{r}3.90 \\
16.30\end{array}$ & $\begin{array}{l}0.04 \\
0.09\end{array}$ & $\begin{array}{l}0.9 \\
0.6\end{array}$ \\
\hline Cholesterol mmol/1 & $\begin{array}{l}5.23 \\
8.20\end{array}$ & $\begin{array}{l}0.06 \\
0.13\end{array}$ & $\begin{array}{l}1.1 \\
1.5\end{array}$ & $\begin{array}{l}4.15 \\
8.84\end{array}$ & $\begin{array}{l}0.08 \\
0.12\end{array}$ & $\begin{array}{l}2.0 \\
1.4\end{array}$ \\
\hline Triacylglycerols $\mathrm{mmol} / 1$ & $\begin{array}{l}1.24 \\
3.68\end{array}$ & $\begin{array}{l}0.02 \\
0.08\end{array}$ & $\begin{array}{l}1.7 \\
2.2\end{array}$ & $\begin{array}{l}1.18 \\
3.72\end{array}$ & $\begin{array}{l}0.01 \\
0.05\end{array}$ & $\begin{array}{l}1.1 \\
1.3\end{array}$ \\
\hline Urea mmol/1 & $\begin{array}{r}6.28 \\
16.20\end{array}$ & $\begin{array}{l}0.21 \\
0.12\end{array}$ & $\begin{array}{l}3.3 \\
5.1\end{array}$ & $\begin{array}{r}5.0 \\
11.1\end{array}$ & $\begin{array}{l}0.11 \\
0.26\end{array}$ & $\begin{array}{l}2.1 \\
2.4\end{array}$ \\
\hline Alanine aminotransferase $U / 1$ & $\begin{array}{l}13.2 \\
42.6\end{array}$ & $\begin{array}{l}0.33 \\
0.88\end{array}$ & $\begin{array}{l}2.5 \\
2.1\end{array}$ & $\begin{array}{l}20.3 \\
51.1\end{array}$ & $\begin{array}{l}0.95 \\
0.57\end{array}$ & $\begin{array}{l}4.7 \\
1.1\end{array}$ \\
\hline Aspartate aminotransferase $\mathrm{U} / 1$ & $\begin{array}{r}7.4 \\
31.8\end{array}$ & $\begin{array}{l}0.26 \\
0.48\end{array}$ & $\begin{array}{l}3.5 \\
1.5\end{array}$ & $\begin{array}{l}11.3 \\
36.6\end{array}$ & $\begin{array}{l}1.06 \\
1.58\end{array}$ & $\begin{array}{l}9.4 \\
4.3\end{array}$ \\
\hline$\gamma$-Glutamyltransferase $\mathrm{U} / \mathrm{l}$ & $\begin{array}{l}20.3 \\
41.4\end{array}$ & $\begin{array}{l}0.89 \\
1.57\end{array}$ & $\begin{array}{l}4.4 \\
3.8\end{array}$ & $\begin{array}{l}19.1 \\
37.1\end{array}$ & $\begin{array}{l}0.32 \\
0.57\end{array}$ & $\begin{array}{l}1.7 \\
1.5\end{array}$ \\
\hline Uric acid $\mu \mathrm{mol} / 1$ & 256 & 6.7 & 2.6 & 268 & 6.3 & 2.3 \\
\hline
\end{tabular}

Tab. 3. Day to day precision; $\mathbf{n}=10$; analyser-specific control specimens.

\begin{tabular}{|c|c|c|c|c|c|c|}
\hline & \multicolumn{3}{|c|}{ Reflotron } & \multicolumn{3}{|c|}{ Ektachem DT 60} \\
\hline & $\overline{\mathbf{x}}$ & $\mathrm{SD}$ & CV (\%) & $\overline{\mathbf{x}}$ & $\mathrm{SD}$ & CV (\%) \\
\hline Glucose mmol/l & $\begin{array}{c}5.60 \\
11.8\end{array}$ & $\begin{array}{l}0.17 \\
0.28\end{array}$ & $\begin{array}{l}3.1 \\
2.4\end{array}$ & 6.20 & 0.19 & 3.1 \\
\hline Cholesterol mmol/l & $\begin{array}{l}4.79 \\
5.96\end{array}$ & $\begin{array}{l}0.14 \\
0.15\end{array}$ & $\begin{array}{l}2.9 \\
2.5\end{array}$ & 6.84 & 0.13 & 1.9 \\
\hline Triacylglycerols $\mathrm{mmol} / \mathrm{l}$ & $\begin{array}{l}2.11 \\
2.58\end{array}$ & $\begin{array}{l}0.17 \\
0.14\end{array}$ & $\begin{array}{l}8.3 \\
5.4\end{array}$ & 1.99 & 0.06 & 3.0 \\
\hline Urea mmol/1 & $\begin{array}{r}7.0 \\
13.6\end{array}$ & $\begin{array}{l}0.37 \\
0.47\end{array}$ & $\begin{array}{l}5.2 \\
3.5\end{array}$ & 9.4 & 0.35 & 3.7 \\
\hline Alanine aminotransferase $U / 1$ & $\begin{array}{l}24.5 \\
51.4\end{array}$ & $\begin{array}{l}0.65 \\
2.26\end{array}$ & $\begin{array}{l}2.7 \\
4.4\end{array}$ & 40.2 & 1.40 & 3.5 \\
\hline Aspartate aminotransferase $U / 1$ & $\begin{array}{l}23.3 \\
49.8\end{array}$ & $\begin{array}{l}1.72 \\
2.42\end{array}$ & $\begin{array}{l}7.4 \\
4.9\end{array}$ & 132.8 & 1.83 & 1.4 \\
\hline$\gamma$-Glutamyltransferase $U / 1$ & $\begin{array}{l}32.6 \\
72.4\end{array}$ & $\begin{array}{l}1.15 \\
3.43\end{array}$ & $\begin{array}{l}3.5 \\
4.7\end{array}$ & 66.9 & 1.52 & 2.3 \\
\hline Uric acid $\mu \mathrm{mol} / 1$ & $\begin{array}{l}297 \\
524\end{array}$ & $\begin{array}{l}20.0 \\
28.7\end{array}$ & $\begin{array}{l}6.7 \\
5.5\end{array}$ & 333 & 8.59 & 2.6 \\
\hline
\end{tabular}

\section{Linearity}

Methods for substrate analysis were linear within the analysis range of both instruments. Table 5 gives an overview of analytical range limits of both solid phase chemistry analysers. Manufacturer's claims for linearity of enzyme determinations are different on the Reflotron and Ektachem DT 60. Linear ranges of alanine aminotransferase and aspartate aminotransferase methods are rather narrow, but were confirmed by our test results.

According to the manufacturer's information, the measuring ranges of alanine aminotransferase, aspartate aminotransferase and $\gamma$-glutamyltransferase as given in the Reflotron operator's manual are esti.8 

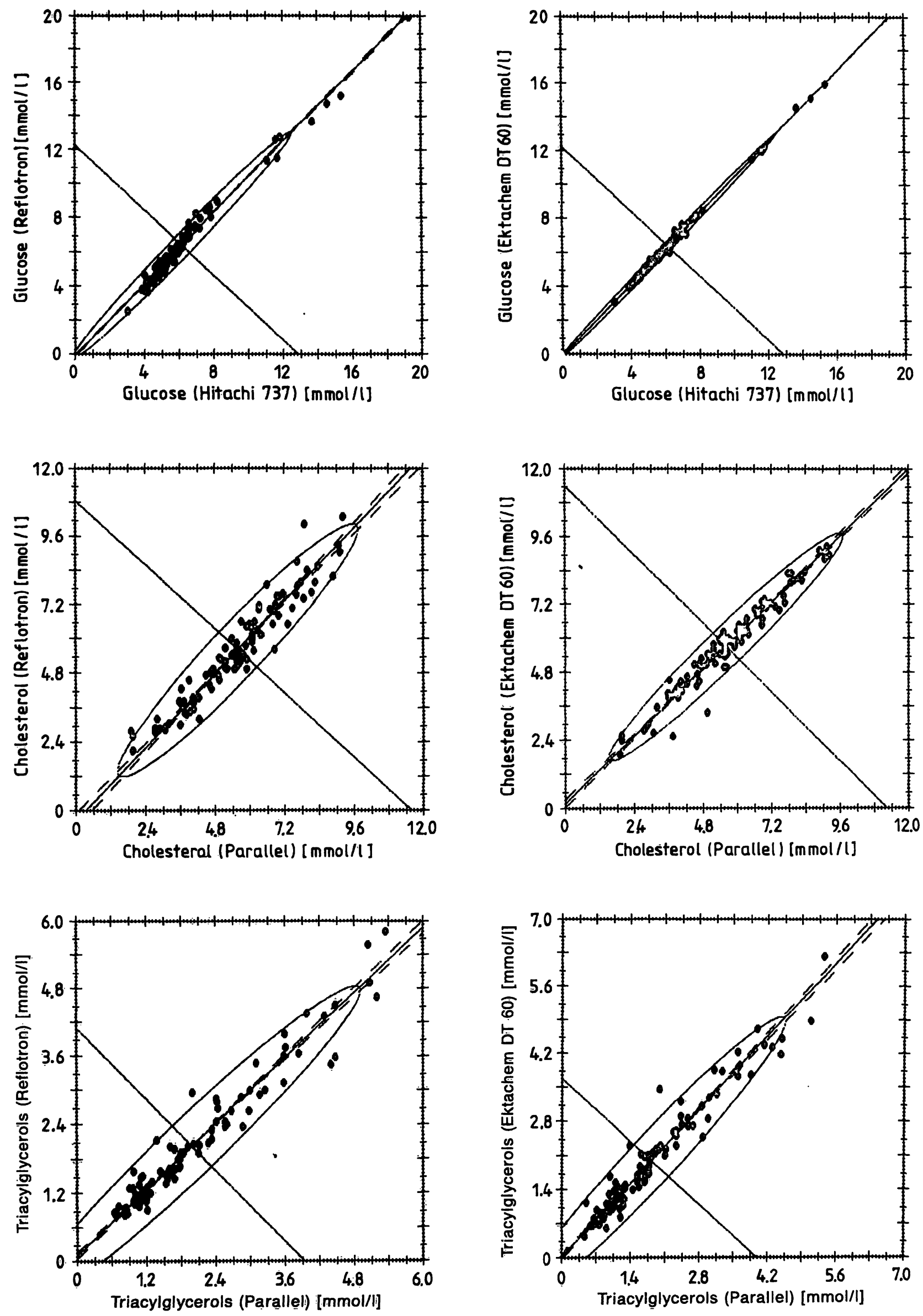

Fig. 1 a. Comparison of Reflotron and Ektachem DT 60 with wet chemistry. Analytes: glucose (reference instrument Hitachi 737), cholesterol and triacylglycerols (reference instrument Parallel). 

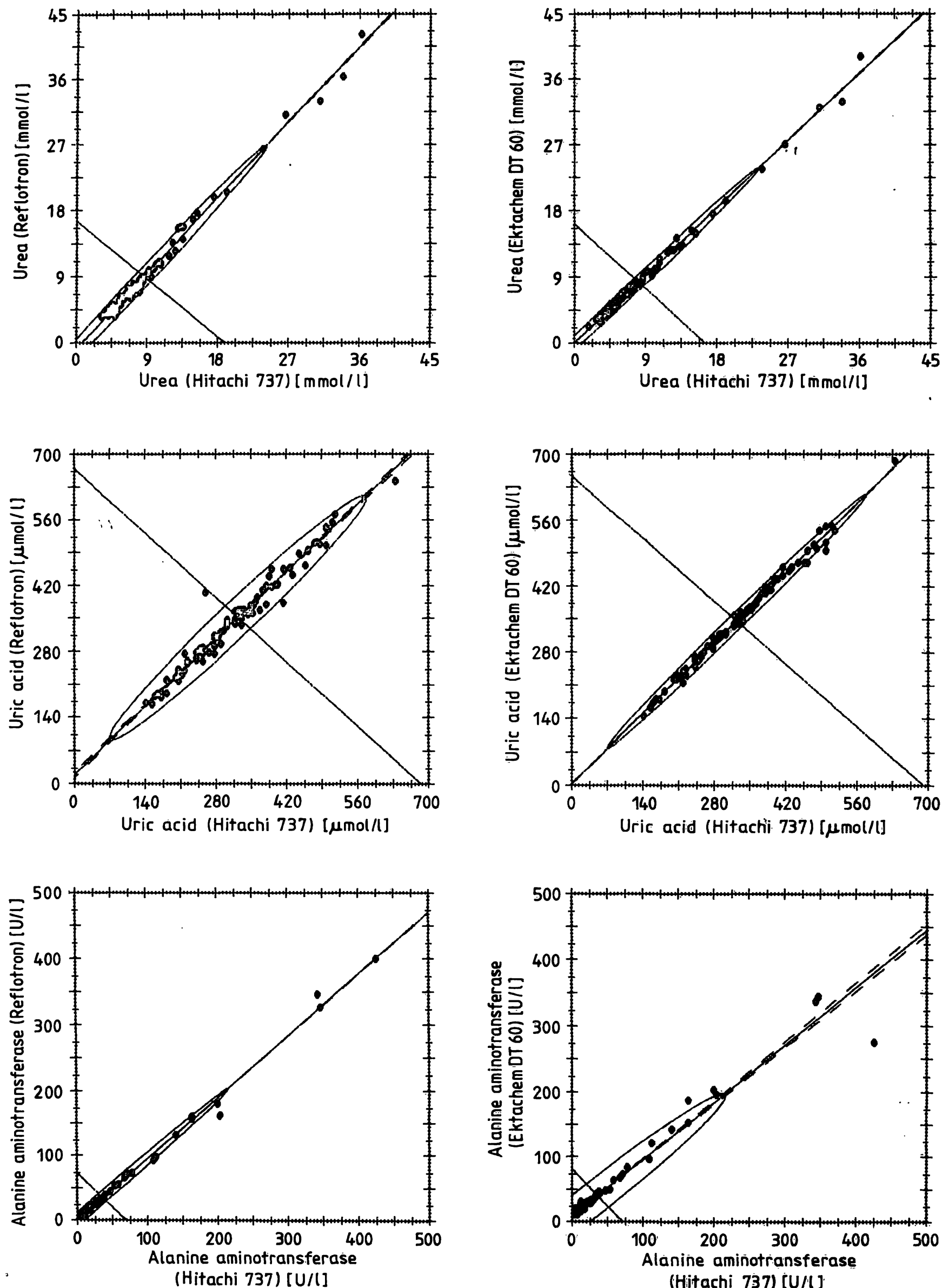

Fig. 1 b. Comparison of Reflotron and Ektachem DT 60 with wet chemistry. Analytes: urea, uric acid and alanine aminotransferase (reference instrument Hitachi 737). 

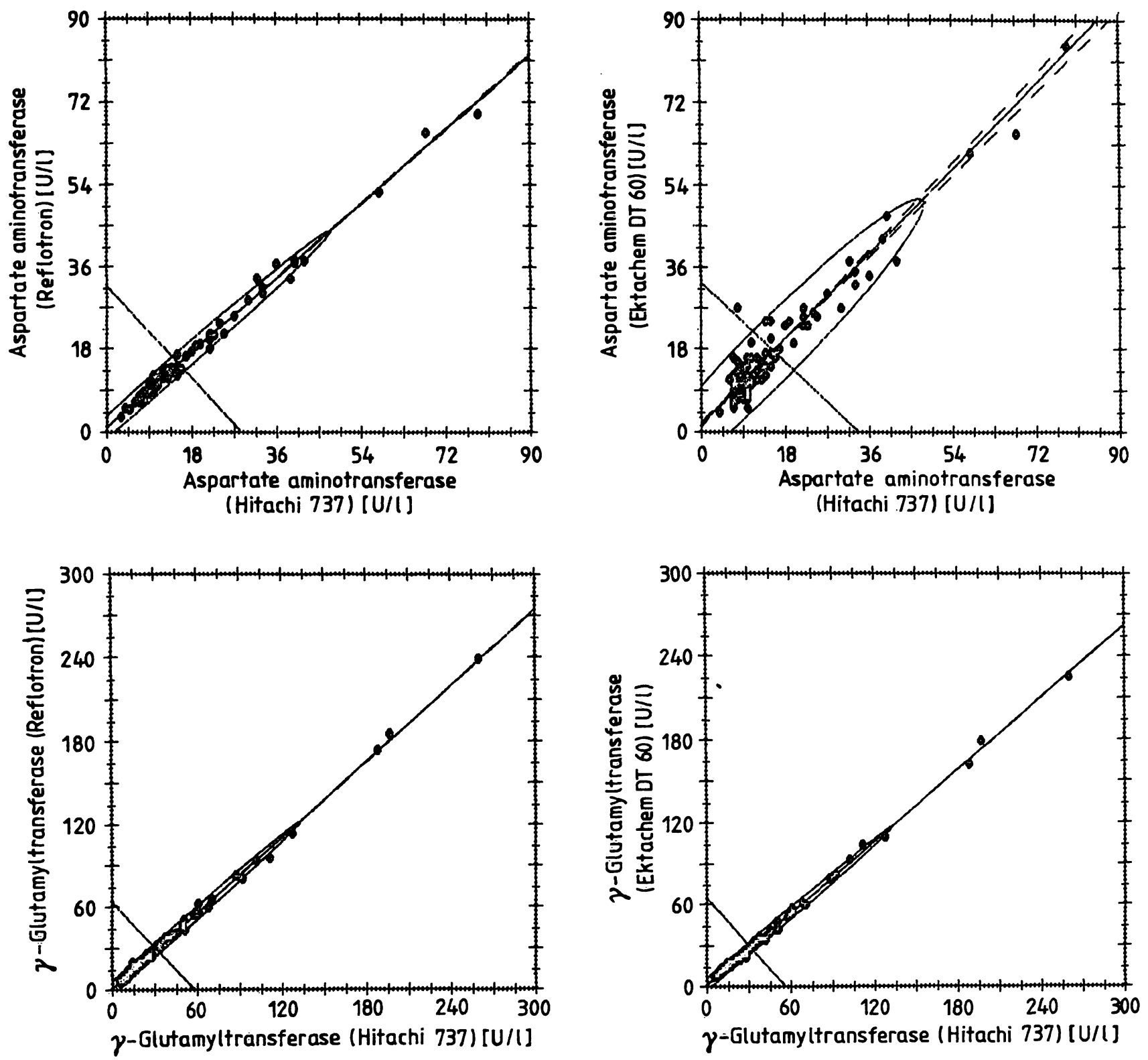

Fig. 1 c. Comparison of Reflotron and Ektachem DT 60 with wet chemistry. Analytes: aspartate aminotransferase and $\gamma$ glutamyltransferase (reference instrument Hitachi 737).

mated data, due to the lack of appropiate testing material with high analyte concentration. Also, the measuring ranges of these analytes are not identical with the linear ranges on the Reflotron. Results outside the linear ranges are flagged on the display of the instrument. Nevertheless, in our study the upper linearity limit of the alanine aminotransferase method was not reached with the Reflotron test strips. As similar results were obtained during an external evaluation trial organized by the producing company (16), the upper limits of alanine aminotransferase measuring range on the Reflotron will be revised.

\section{Practicability}

Practicability data are summarized in tables 6 and 7 and are discussed in the following paragraph.

\section{Discussion}

Solid phase chemistry tests are discussed below with respect to their reliability, application and cost effectiveness.

\section{Reliability}

The results of our study confirm the precision of solid phase chemistry instruments. Moreover, results from the solid phase chemistry methods are in close agreement with those from wet chemistry measurements, and the linearity of solid phase chemistry methods is good. Two problems have to be considered, calibration and quality control.

In solid phase chemistry a complex mathematical function describes the nonlinear relationship between 


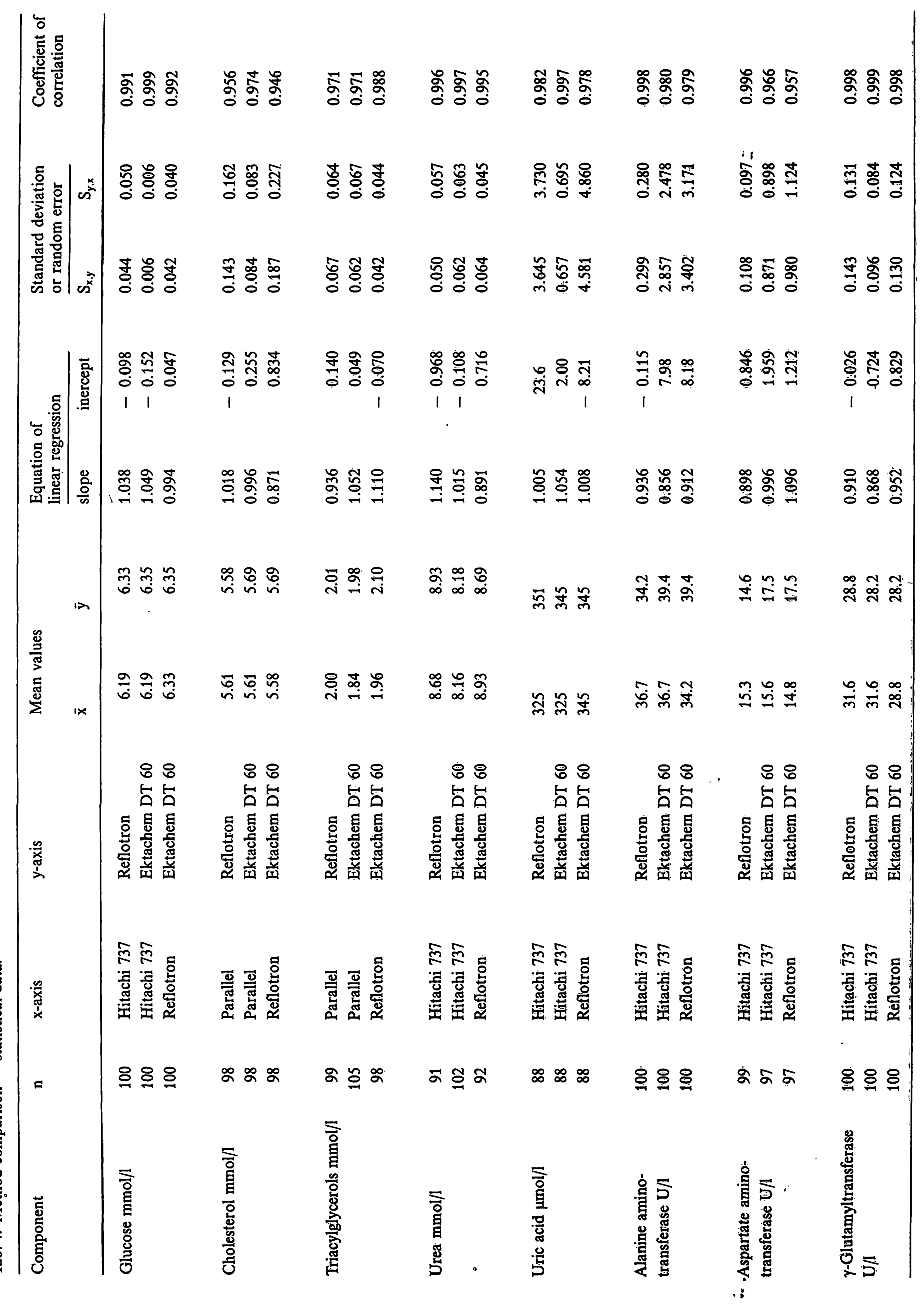


Tab. 5. Analytical ranges of linearity for Reflotron and Ektachem DT 60.

\begin{tabular}{|c|c|c|c|c|c|c|}
\hline & \multicolumn{2}{|c|}{ Manufacturer's claims } & \multicolumn{4}{|c|}{ Our results } \\
\hline & Reflotron & Ektachem DT 60 & \multicolumn{2}{|c|}{ Reflotron } & \multicolumn{2}{|c|}{ Ektachem DT 60} \\
\hline Glucose mmol/1 & $0.86-33.30$ & $1.11-24.98$ & \multicolumn{2}{|c|}{$2.20-32.80$} & \multicolumn{2}{|c|}{$2.20-32.80$} \\
\hline Cholesterol mmol/l & $2.07-12.95$ & $1.30-11.01$ & \multicolumn{2}{|c|}{$2.59-12.43$} & \multicolumn{2}{|c|}{$1.55-10.88$} \\
\hline Triacylglycerols mmol/ & $0.80-\quad 6.84$ & $0.29-4.56$ & \multicolumn{2}{|c|}{$0.80-6.84$} & \multicolumn{2}{|c|}{$0.51-4.56$} \\
\hline Urea mmol/1 & $3.30-50.00$ & $1.68-35.60$ & \multicolumn{2}{|c|}{$4.20-42.60$} & \multicolumn{2}{|c|}{$1.70-35.80$} \\
\hline Uric acid $\mu \mathrm{mol} / 1$ & $119-1190$ & $60-952$ & 179 & $-892^{+}$ & 179 & $-892^{+}$ \\
\hline Alanine aminotransferase $U / 1$ & $2.70-1060$ & $1.60-385$ & 5 & $\begin{array}{l}-450 \\
-750 *\end{array}$ & 5 & -360 \\
\hline Aspartate aminotransferase $\mathrm{U} / 1$ & $2.30-675$ & $1.90-408$ & 8 & $\begin{array}{l}-450 \\
-750^{*}\end{array}$ & 6 & -390 \\
\hline$\gamma$-Glutamyltransferase $U / 1$ & $2.80-2000$ & $1.80-784$ & 6 & $-840^{+}$ & 5 & -680 \\
\hline
\end{tabular}

+ no sample with higher analyte concentration available

* reached upper limit, but flagged on instrument display (result out of linarity range)

Tab. 6. Practicability data of Reflotron and Ektachem DT 60.

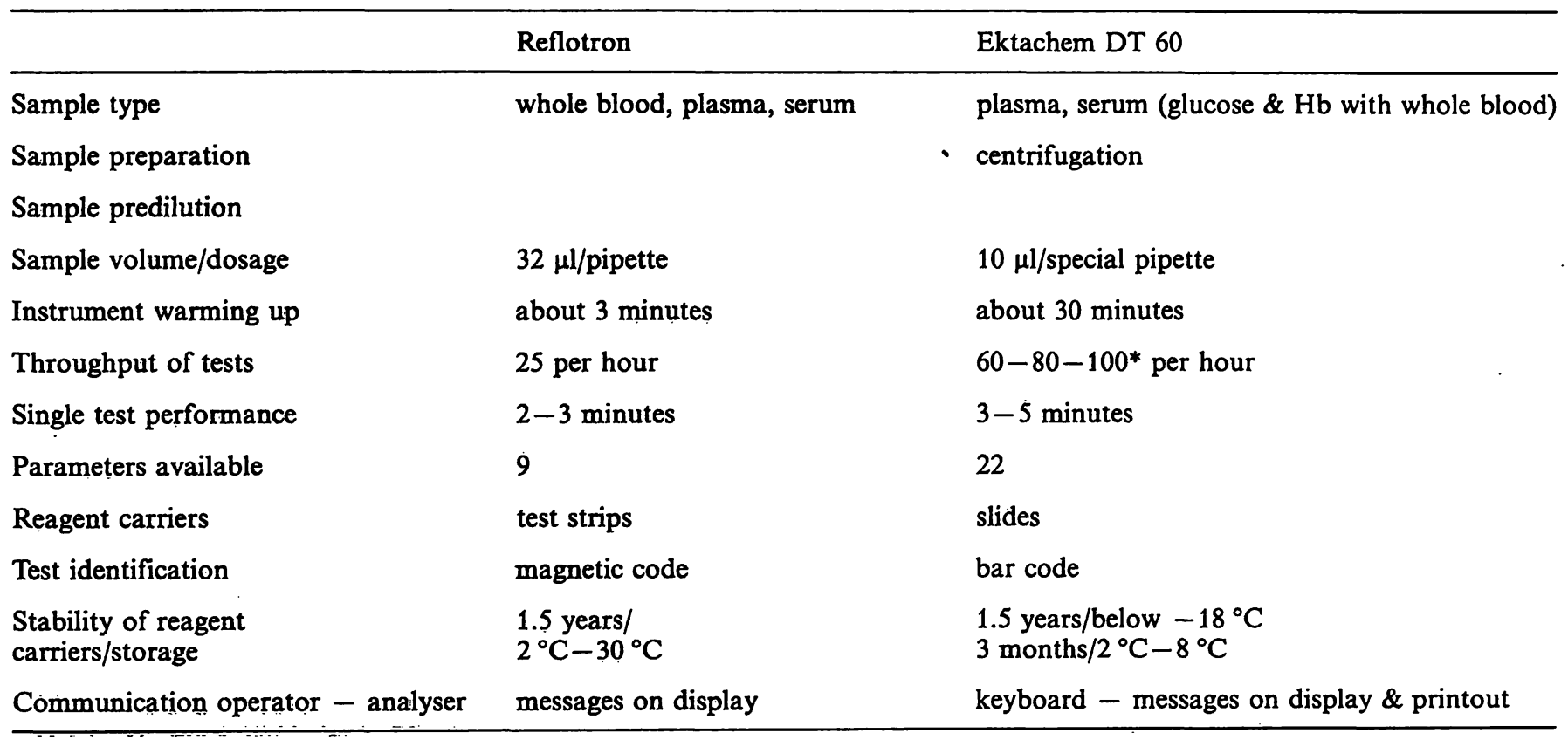

* depending on number of modules running

Tab. 7. Practicability data continued.

\begin{tabular}{|c|c|c|}
\hline & Reflotron & Ektachem DT 60 \\
\hline Calibration performance & - & $\begin{array}{l}2 \text { or } 3 \text { point calibration according } \\
\text { instruction manual } \\
\text { at least every } 3 \text { months }\end{array}$ \\
\hline Optical quality control & grẹy test strips (CHEK strips) operator & LED test service technologist \\
\hline Chemical quality control & $\begin{array}{l}\text { analyser-specific control material } \\
\text { for Reflotron }\end{array}$ & analyser-specific control material \\
\hline Working temperature & $37^{\circ} \mathrm{C}$ & $37^{\circ} \mathrm{C}$ \\
\hline $\begin{array}{l}\text { Reference temperature } \\
\text { for enzyme kinetic assays }\end{array}$ & $\begin{array}{l}25^{\circ} \mathrm{C}, 30^{\circ} \mathrm{C}, 37^{\circ} \mathrm{C} \text { choice by switchkey } \\
\text { (operator) }\end{array}$ & $\begin{array}{l}25^{\circ} \mathrm{C}, 30^{\circ} \mathrm{C}, 37^{\circ} \mathrm{C} \text { programmable by } \\
\text { service technologist }\end{array}$ \\
\hline Units & $\begin{array}{l}\text { S.I. or conventional choice by switchkey } \\
\text { (operator) }\end{array}$ & $\begin{array}{l}\text { S.I. or conventional programmable by } \\
\text { service technologist }\end{array}$ \\
\hline Data interface & Centronics & RS 232 C \\
\hline Maintenance & little & little \\
\hline
\end{tabular}


analyte concentration and the reflection intensity of the reagent carrier. These mathematical functions are largely the same in Reflotron and Ektachem systems. For Ektachem tests calibration curves are stored in the calibration data module (CDM) which is part of the central processing unit (CPU) of the analyser. When calibration is performed, measured values of calibration sera are compared with assigned values in the CDM. In this way intercept, slope and curvature of the calibration curve can be adapted to actual chemical and optical conditions. With one lot of urea slides, we experienced a systematic drift of results, without the control values being affected. Therefore the calibration frequency of the Ektachem DT 60 should be further investigated (17).

For the Reflotron, test-specific calibration data are stored in magnetic code on test strips. Changes in optical environment are equalized by Ulbricht's sphere, the essential optical part of the Reflotron (18). A reference photodiode receives only light reflected from inside the sphere which is comparable to a wet chemistry blank. There is no possibility of adjustment to chemical changes, such as test strip ageing.

Internal quality control on the Reflotron and Ektachem can only be performed with analyser-specific control fluids. Matrix effects are of considerable influence $(19,20)$, since undiluted samples are used in solid phase chemistry. We tried Precinorm $U$ for Universal Use, Precipath $U$ for Universal Use (Boehringer Mannheim GmbH, Mannheim, W. Germany), and Kontrollogen LP (Behring Werke AG, Marburg, W. Germany) on both instruments. With Precinorm $U$ and Precipath $U$ for Universal Use only urea measurements were within the reference range of the corresponding chemical method. For the other analytes of our study the Reflotron and Ektachem showed deviations from specified values of $+3 \mathrm{~s}$ to $-7 \mathrm{~s}$. With Kontrollogen LP better results were obtained. On the Reflotron we found cholesterol and urea measurements outside the reference range, on the Ektachem only urea. Without special control ranges for the solid phase chemistry analysers, use of commercial control material is difficult. Extcrnal quality control for solid phase chemistry was started in Austria in 1986. The first Reflotron ficld study was realixed by the national quality assurance committce (ÖQUASTA) in Junc 1986. Fifteen perecnt of participant laboratories demonstrated one or more values outside the 4 s range of the specified value').

1) ()esterrelelifsche (Besclischilt thr Quilitätssicheming und Slindardisiorung medizinisch-dlizgnostischer Untersu-

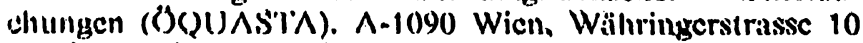
"Refluleron licldversuch" ol" Junc 1". 1986.
A second trial in December 1986 showed a decrease in the number of rough outliers, but indicated that there are sources of error in handling samples and instruments ${ }^{2}$ ).

It should be mentioned that no control values were available for Precinorm $U$ and Precipath $U$ for the Reflotron for alanine aminotransferase, aspartate aminotransferase and uric acid at the time of our study. Test strips for these analytes were already sold commercially.

\section{Application of solid phase chemistry sys-} tems

Reflotron and Ektachem DT 60 are analysers designed for so called real time analysis (21), mainly in the physician's office.

No general recommendations can be given by the authors, with regard to which system is appropiate for which place. The number of tests per day, the required parameters, batchwise or single test performance, laboratory equipment and storage facilities are matters for consideration. Single test results are available in about 3 minutes, whereas series are time consuming on both instruments. Ektachem offers a greater variety of methods, which makes it suitable for small laboratories or even hospital central laboratories for analysis of analytes of low incidence. If stored for long periods, the single sealed Ektachem slides must be kept at $-18^{\circ} \mathrm{C}$, but have to reach room temperature before use. According to the manufacturer's recommendation they can remain at this temperature for up to 48 hours. The reagent carrier stability under different conditions will be subject of a further study in our laboratory. Reflotron test strips can be stored at room temperature. Both instruments require little maintenance. Advantages of solid phase chemistry analysers are small sample volumes $(10 \mu \mathrm{l}$ or $32 \mu \mathrm{l})$ and the use of whole blood. All Reflotron test strips can be used with whole blood plasma or serum samples. Throughout our study we used only serum, for reasons related to the organization in the clinical chemistry department of a hospital central laboratory. The design of solid phase chemistry reagent carriers provides a facility for separating blood cells as well as the filtration of interfering substances. On the other hand, the flow properties of the sample liquid are important. and

Dircetors of trial: Univ. Prof. Dr. M. M. Müller, Univ. Prof. Dr. is Kaiscr.

2) SQUASTA - "Roflottrn-Faldvarsuch" Docember $10^{\text {ih }}$. $1980^{\circ}$

Diroctors: Univ. Pror. Dr. M. M. Müller, Unin. Pror, Dr. E. Naiser. 
application of an undiluted sample increases the possibility of endogenous and exogenous interferences $(7,22,23,24)$.

\section{Costs}

Reagent costs of solid phase chemistry tests are two to ten times higher than those of wet chemistry serial tests. The simplicity of operating solid phase chemistry analysers is often emphasized. Nevertheless, high reagent costs of solid phase chemistry tests, which become more important as the size of the test series increases $(25)$ cannot be regained by lowering person-

\section{References}

1. Zipp, A. (1981) J. Autom. Chem. 3, 71-75.

2. Libeer, J. C. (1985) J. Clin. Chem. Clin. Biochem. 23, 645655.

3. Maumene, M. (1850) C. R. Acad. Sci. 30, 314-315.

4. Spayd, R. W., Bruschi, B., Burdick, B. A., Dappen, G. M., Eikenberry, J. N., Esders, T. W., Figueras, J., Goodhue, C. T., LaRossa, D. D., Nelson, R. W., RAnd, R. N. \& Wu, T. W. (1978) Clin. Chem. 24, 1343-1350.

5. Burnett, D., Barbour, H. M., Woods, T. F., Vassault, A., Sebille, L., Bailly, M., Haeckel, R., Sonntag, O., Bugiardini, G. \& Motta, R. (1982) J. Clin. Chem. Clin. Biochem. 20, 207-215.

6. Knoll, E., Hafner, F., Dettmer, K. \& Wisser, H. (1982) J. Clin. Chem. Clin. Biochem. 20, 492-498.

7. Wisser, H., Knoll, E. \& Ratge, D. (1986) J. Clin. Chem. Clin. Biochem. 24, 147-154.

8. Price, C. P. \& Koller, P. U. (1987) J. Clin. Chem. Clin. Biochem. submitted.

9. Ratge, D., Kohse, K. P., Knoll, E. \& Wisser, H. (1986) J. Clin. Chem. Clin. Biochem. 24, 789.

10. Hicks, Jocelyn M. \& Iosephson, Mariet (1986) Clin. Chem. 32, $2201-2203$.

11. Reflometrie (1984) Möglichkeiten der sogenannten Trokkenchemie. Vortragsreihe anläßlich der MEDICA $1983 \mathrm{mit}$ Diskussionsbeiträgen, Düsseldorf, W. Germany, by Boehringer Mannheim $\mathrm{GmbH}$.

12. Curme, H. G., Columbus, R. L., Dappen, G. M., Eder, T. W., Fellows, W. D., Figueras, J., Glover, C. P., Goffe, C. A., Hill, D. E., Lawton, W. H., Muka, E. J., Pinney, J. E., Rand, R. N., Sanford, K. J. \& Wu, T. W. (1978) Clin. Chem. 24, 1335-1342. nel costs. Well trained personnel are required to operate both the Reflotron and the Ektachem DT 60 (26). The benefit of a quick bedside result is diminished if implausible values arising from incorrect handling have to be reinvestigated in the routine laboratory.

\section{Acknowledgement}

Authors wish to thank Univ. Doz. Dr. H. Rumpold for valuable discussion and cand. med. $E$. Strutzenberger for her assistance in performing tests for alanine aminotransferase and $\gamma$-glutamyltransferase. Test strips were kindly provided by Boehringer Mannheim $\mathrm{GmbH}$, slides by Eastman Kodak Co.

13. Haeckel, R. (1979) GIT Lab. Med. 2, 201-205.

14. Shirey, T. L. (1983) Clin. Biochem. 16, 147-155.

15. Feldmann, U., Schneider, B., Klinkers, H. \& Haeckel, R. (1981) J. Clin. Chem. Clin. Biochem. 19, 121-137.

16. Workshop Report 2 Reflotron System (1986) Frankfurt am Main, W. Germany, 23. Mai 1986, by Boehringer Mannheim.

17. Bernat, J. \& Rousselet, F. (1981) J. Clin. Chem. Clin. Biochem. 19, 613.

18. Schlicht, G. (1984) Lab. Med. 8, 311-313.

19. Clark, P. M. S., Whitehead, T. P., Gamo, R. A. Z. \& Kricka, L. J. (1980) Clin. Chem. 26, 1980.

20. Keller, H. (1985) Lecture given at MEDICA congress 1984, Düsseldorf, W. Germany, by Boehringer Mannheim.

21. Thomas, L. (1986) Lab. Med. 10, 153-159.

22. Haeckel, R. \& Sonntag, O. (1979) GIT Lab. Med. 2, 317327.

23. Workshop Report Reflotron System (1985) Baden-Baden, W. Germany, 9. Mai 1985, by Boehringer Mannheim.

24. Glick, M. R., Ryder, K. W. \& Jackson, S. A. (1986) Clin. Chem. 32, 470-475.

25. Plischke, W. (1984) Lab. Med. 8, 314-317.

26. Broughton, P. M. G. \& Buckley, B. M. (1987) Scand. J. Clin. Lab. Invest. 47, 99-104.

Dr. Madeleine Rohac Institut für Klinische Chemie und Laboratoriumsdiagnostik der Universität Wien Lazarettgasse 14 A-1090 Wien 
